\title{
Neuronal Somata and Extrasomal Compartments Play Distinct Roles during Synapse Formation between Lymnaea Neurons
}

\author{
Fenglian Xu, ${ }^{\star}$ Collin C. Luk, ${ }^{\star}$ Ryanne Wiersma-Meems, Kelly Baehre, Cameron Herman, Wali Zaidi, Noelle Wong, \\ and Naweed I. Syed \\ Department of Cell Biology and Anatomy, Hotchkiss Brain Institute, Faculty of Medicine, University of Calgary, Alberta T2N 4Z6, Canada
}

\begin{abstract}
Proper synapse formation is pivotal for all nervous system functions. However, the precise mechanisms remain elusive. Moreover, compared with the neuromuscular junction, steps regulating the synaptogenic program at central cholinergic synapses remain poorly defined. In this study, we identified different roles of neuronal compartments (somal vs extrasomal) in chemical and electrical synaptogenesis. Specifically, the electrically synapsed Lymnaea pedal dorsal A cluster neurons were used to study electrical synapses, whereas chemical synaptic partners, visceral dorsal 4 (presynaptic, cholinergic), and left pedal dorsal 1 (LPeD1; postsynaptic) were explored for chemical synapse formation. Neurons were cultured in a soma-soma or soma-axon configuration and synapses explored electrophysiologically. We provide the first direct evidence that electrical synapses develop in a soma-soma, but not soma-axon (removal of soma) configuration, indicating the requirement of gene transcription regulation in the somata of both synaptic partners. In addition, the soma-soma electrical coupling was contingent upon trophic factors present in Lymnaea brain-conditioned medium. Further, we demonstrate that chemical (cholinergic) synapses between soma-soma and soma-axon pairs were indistinguishable, with both exhibiting a high degree of contact site and target cell type specificity. We also provide direct evidence that presynaptic cell contact-mediated, clustering of postsynaptic cholinergic receptors at the synaptic site requires transmitter-receptor interaction, receptor internalization, and a protein kinase C-dependent lateral migration toward the contact site. This study provides novel insights into synaptogenesis between central neurons revealing both distinct and synergistic roles of cell-cell signaling and extrinsic trophic factors in executing the synaptogenic program.
\end{abstract}

Key words: electrical synapses; chemical synapses; synapse formation; trophic factors; somata; axons

\section{Introduction}

Neuronal communications rely upon chemical or electrical synapses formed between cells. At a chemical synapse, distinct presynaptic and postsynaptic specializations are in opposition across a synaptic cleft, whereas an electrical synapse lacks such morphological characteristics. Instead, communications are achieved via fused membranes involving specific gap junction-forming proteins (e.g., the connexins, innexins, or pannexins) (Veenstra et al., 1995; Bennett and Zukin, 2004). Electrical synapses play important roles in mediating fast reflexes in invertebrates (Furshpan and Potter, 1959; Hagiwara and Morita, 1962) and perhaps a more prominent, albeit transient, developmental role in synchronizing activity among groups of vertebrate neurons, such as Purkinje fibers, inhibitory interneurons (Weidmann, 1952; Gibson et al., 1999). A number of studies have also demonstrated that

\footnotetext{
Received April 23, 2014; revised June 7, 2014; accepted July 15, 2014.

Author contributions: F.X., C.C.L., and N.I.S. designed research; F.X., R.W.-M., K.B., C.H., W.Z., N.W., and N.I.S. performed research; R.W.-M., C.H., and N.I.S. contributed unpublished reagents/analytic tools; F.X., C.C.L., and N.I.S. analyzed data; F.X. wrote the paper.

This work was supported by Natural Sciences and Engineering Research Council of Canada discovery grant.

The authors declare no competing financial interests.

*F.X. and C.C.L. contributed equally to this work.

Correspondence should be addressed to Dr. Naweed I. Syed, Department of Cell Biology and Anatomy,

Hotchkiss Brain Institute, Faculty of Medicine, University of Calgary, Calgary, Alberta T2N 4Z6, Canada. E-mail: nisyed@ucalgary.ca.

DOI:10.1523/JNEUROSCI.1651-14.2014

Copyright $\odot 2014$ the authors $\quad 0270-6474 / 14 / 3411304-12 \$ 15.00 / 0$
}

electrical coupling precedes chemical synapse formation during development (Curtin et al., 2002; Szabo et al., 2004; Todd et al., 2010) and vice versa (Leitch et al., 1989; Nicholls et al., 1990), suggesting an interdependence of these two modes of communication in defining the final pattern of neuronal connectivity in the brain. However, the mechanisms underlying the development of electrical synapses are not well understood.

Significant progress has thus been made toward understanding and identifying key steps (axon path finding, cell-cell signaling) and molecules (axon guidance, cell recognition, cell adhesion molecules) involved in chemical synaptogenesis (Horch and Katz, 2002; Dalva et al., 2007; Shen and Cowan, 2010). Moreover, both intrinsic cellular signaling (genetic information) and extrinsic factors (e.g., trophic factors, morphogens) are considered important for chemical synapse formation (Sotelo and Dusart, 2009; Terauchi and Umemori, 2012). Despite these advances, many key questions regarding the development of both chemical and electrical synapses remain unanswered. For instance, the precise contributions and innate propensity of various neuronal compartments (somata, dendrite, and axon) to form electrical or chemical synapses remain to be well characterized. Likewise, the interplay between cell-cell signaling and extrinsic factors in defining the temporal/spatial patterns of synapse formation in the somal or extrasomal compartments has yet to be fully defined.

Neurons isolated from invertebrate species, such as Aplysia (Bodmer et al., 1988; Carrow and Levitan, 1989), Lymnaea (Syed 
et al., 1990; Feng et al., 1997), Hirudo medicinalis (Nicholls et al., 1990; Todd et al., 2010), and Helisoma (Barker et al., 1982; Hadley et al., 1985; Neunuebel and Zoran, 2005), have proven valuable in identifying steps underlying synapse formation. Previous studies using invertebrate neurons have demonstrated that axons severed from their cell bodies after forming chemical synapses are capable of maintaining synaptic function in culture for several days, in the absence of either or both somata of partner cells (Schacher and Wu, 2002; Meems et al., 2003). In Lymnaea, we have previously demonstrated that the formation of new synapses between axons requires the presynaptic but not the postsynaptic somata (Meems et al., 2003). However, neither the specificity of synaptogenesis nor the underlying mechanisms were identified. In this study, we studied the contribution of somal versus extrasomal compartments and the role of trophic factors in chemical and electrical synaptogenesis using the Lymnaea soma-soma and soma-axon model.

\section{Materials and Methods}

Animals and cell culture. Fresh pond snails, Lymnaea stagnalis (hermaphroditic), were maintained at room temperature in a well-aerated aquarium containing filtered pond water at the University of Calgary's animal care facility. For experiments involving cell culture, snails $\sim 1-2$ months old (shell length of $18-20 \mathrm{~mm}$ ) were used, whereas Lymnaea brainconditioned medium (CM, containing trophic factors) was prepared from 2- to 3-month-old animals (shell length of 20-30 mm).

Neurons were isolated from the central ring ganglia and maintained in cell culture as described previously (Syed et al., 1990; Ridgway et al., 1991). Briefly, snails were deshelled and anesthetized for $10 \mathrm{~min}$ with Listerine solution (ethanol, 21.9\%; and methanol, $0.042 \%$ ) diluted to $10 \%$ in normal saline (in $\mathrm{mm}$ as follows: $\mathrm{NaCl} 51.3, \mathrm{KCl} 1.7, \mathrm{CaCl}_{2} 4.0$, $\mathrm{MgCl}_{2} 1.5$, HEPES 10) adjusted to $\mathrm{pH}$ 7.9. The central ring ganglia were then treated with trypsin $(2 \mathrm{mg} / \mathrm{ml})$, a proteolytic enzyme, dissolved in defined medium (DM; L-15; Invitrogen; special order) containing the following (in $\mathrm{mM}$ ) as follows: $\mathrm{NaCl} 40, \mathrm{KCl} 1.7, \mathrm{CaCl}_{2} 4.1, \mathrm{MgCl}_{2} 1.5$, HEPES 10.0 for $21 \mathrm{~min}$. Subsequently, the central ring ganglia were placed in a DM solution containing trypsin inhibitor $(2 \mathrm{mg} / \mathrm{ml})$ for 15 min. The central ring ganglia were then pinned on a dissection dish containing high osmolarity DM (D-glucose, $20 \mathrm{~mm}$ ), and brains were visualized using a dissection microscope (Stemi 2000, Zeiss). Fine forceps were used to remove the thin inner layer of sheath surrounding the ganglia. Individual cells were then removed via gentle suction applied through a Sigmacote-treated, fire polished pipette attached to a microsyringe filled with high osmolarity DM. Upon extraction, specific cells were juxtaposed either in a soma-soma or soma-axon configuration (see Figs. 1 and 3) on poly-L-lysine-coated culture dishes containing culture medium. Isolated axon preparations were made according to previously established protocols (Meems et al., 2003). In brief, after the initial isolation of neuronal soma and axon in culture, a conventional intracellular electrode attached to a micromanipulator was used to manually sever the axon from its soma at an area adjacent to the axonal hillock. The isolated axon was subsequently paired via juxtaposition with the soma or axon of its partner cell. To study electrical coupling, pedal dorsal A (PeA) cells were isolated and paired in a soma-soma, soma-axon, or axon-axon configuration (see Fig. 1). PeA cluster cells in vivo are homogenous clusters of electrically coupled neurons ( $\sim 30$ neurons/ ganglia) located in the pedal ganglia. These neurons are electrically coupled to both ipsilateral and contralateral counterparts, exhibit serotonergic phenotype and innervate the pedal locomotor cilia in Lymnaea (Kyriakides et al., 1989; Syed and Winlow, 1989). To study chemical synapses, the presynaptic neuron, visceral dorsal 4 (VD4, cholinergic), and its postsynaptic partner, left pedal dorsal 1 (LPeD1) were cultured as shown in Figure 3. VD4 and LPeD1 neurons in vivo form excitatory chemical synapses and are involved in the control of cardiorespiratory behavior in Lymnaea (Buckett et al., 1990; Syed and Winlow, 1991). To elucidate the roles of trophic factors in electrical and chemical synapse formation, we cultured neurons in the presence of Lymnaea CM. Despite the fact that specific neu- rotrophic molecules in Lymnaea CM are yet to be fully identified and characterized, previous studies from our laboratory have demonstrated that CM-induced effects on neurite outgrowth and/or synapse formation are mimicked by a variety of vertebrate growth factors, such as NGF (Ridgway et al., 1991), CNTF (Syed et al., 1996), and EGF (Hamakawa et al., 1999; Munno et al., 2000; van Kesteren et al., 2008) and that these molecules and their functions are conserved across the species. Lymnaeaderived trophic factors, such as Lymnaea EGF, when used individually, however, only partially mimic CM-induced synapse formation in vitro (Hamakawa et al., 1999; van Kesteren et al., 2008). In this study, we thus opted to use CM, which contains the full complement of physiologically relevant and naturally occurring trophic molecules.

$\mathrm{CM}$ was prepared by isolating the central ring ganglia, which were subsequently washed $6-8$ times in normal saline solution containing 50 $\mu \mathrm{g} / \mathrm{ml}$ of gentamycin. Twelve central ring ganglia were then incubated in $6.5 \mathrm{ml}$ of DM for varying periods of time in Sigmacote-treated glass Petri dishes. In brief, ganglia were removed and $\mathrm{CM}$ was collected following a $3 \mathrm{~d}$ incubation period in a humidified chamber at room temperature $\left(22^{\circ} \mathrm{C}-23^{\circ} \mathrm{C}\right)$. Ganglia were then washed in saline containing gentamycin and placed in fresh DM for two subsequent incubations of 4 and $6 \mathrm{~d}$, respectively.

Electrophysiology. Intracellular recording techniques were used to investigate synaptic physiology between the paired cells. Recordings were made from both presynaptic and postsynaptic partners using sharp electrodes. Glass microelectrodes (1.5 mm internal diameter; World Precision Instruments) were pulled using a vertical pipette puller (Model 700C, David Kopf Instruments) and were backfilled with a saturated solution of $\mathrm{K}_{2} \mathrm{SO}_{4}$ to obtain a tip resistance in the range of $20-40 \mathrm{M} \Omega$. Paired neurons were visualized using an inverted microscope (Axiovert 200, Zeiss) and impaled with Narishige micromanipulators (MM-202 and MM-204). Electrical signals were amplified with a Neuro Data amplifier (Neuron Data Instrument) and recorded with Axoscope (Molecular Devices). MiniAnalysis software was used to extract membrane potential data, which, in turn was exported to Microsoft Excel and Origin Pro 8 for analysis.

Electrical coupling was measured according to the protocol described by Szabo et al. (2004). Specifically, square pulses of hyperpolarizing currents ranging from 0.1 to $0.3 \mathrm{nA}$ were injected into one of the PeA cells (PeA-1) for 2 to $3 \mathrm{~s}$, whereas the changes in membrane potentials of both the injected cell 1 (PeA-1) and the noninjected cell 2 (PeA-2) were monitored by intracellular recording. The electrical coupling coefficient was determined as the ratio of voltage change in PeA-2 over PeA-1 ( $\triangle \mathrm{PeA}-2$ ) $\Delta$ PeA-1) (Szabo et al., 2004). Chemical synapses were measured by intracellular recordings of both presynaptic and postsynaptic cells. Specifically, depolarizing currents $(50-150 \mathrm{pA}$ for $0.5-1 \mathrm{~s})$ were injected into VD4 soma to trigger single or bursts of action potentials and the elicited single or compound EPSPs were recorded. Percentage of synapse formation was determined as the number of pairs that exhibited quantifiable transmission of stimuli between cells, out of the total number of pairs examined. The synaptic strength was determined by measuring the mean amplitude of five successive EPSPs in response to presynaptic single action potentials. The post-tetanic potentiation, a well-characterized short-term plasticity in Lymnaea (Luk et al., 2011), was determined by measuring the values of EPSP amplitude post-tetanus (pEPSP) over the EPSP amplitude before the tetanic stimulation (pEPSP/EPSP). The increase in the $\mathrm{pEPSP/EPSP}$ ratio is defined as post-tetanic potentiation (as shown in Fig. 3B). The tetanic stimulation was induced by current injection of $\sim 2 \mathrm{~s}$ in duration.

To test the responsiveness of postsynaptic nicotinic acetylcholine receptors (nAChRs), exogenous acetylcholine (ACh; $1 \mu \mathrm{M})$ was pressure applied ( $10 \mathrm{psi}, 0.2 \mathrm{~s}$ duration) directly to the somata or axonal compartments through a glass pipette (2-4 $\mu \mathrm{m}$ tip in diameter) connected to a PV800 pneumatic picopump (World Precision Instruments).

Chemicals. ACh, hexamethonium chloride, Dynasore, chelerythrine chloride, phorbol-12-myristate-13-acetate (PMA), and all other chemicals were obtained from Sigma-Aldrich.

Data analysis. The values are presented as the mean \pm SEM. Significance for the percentage of cells that exhibited electrical or chemical 
A
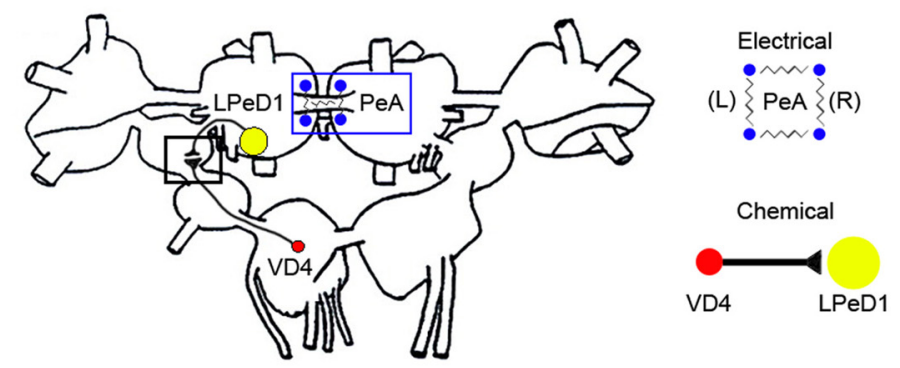

B
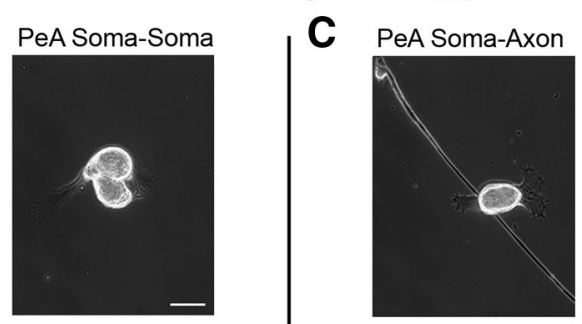

D
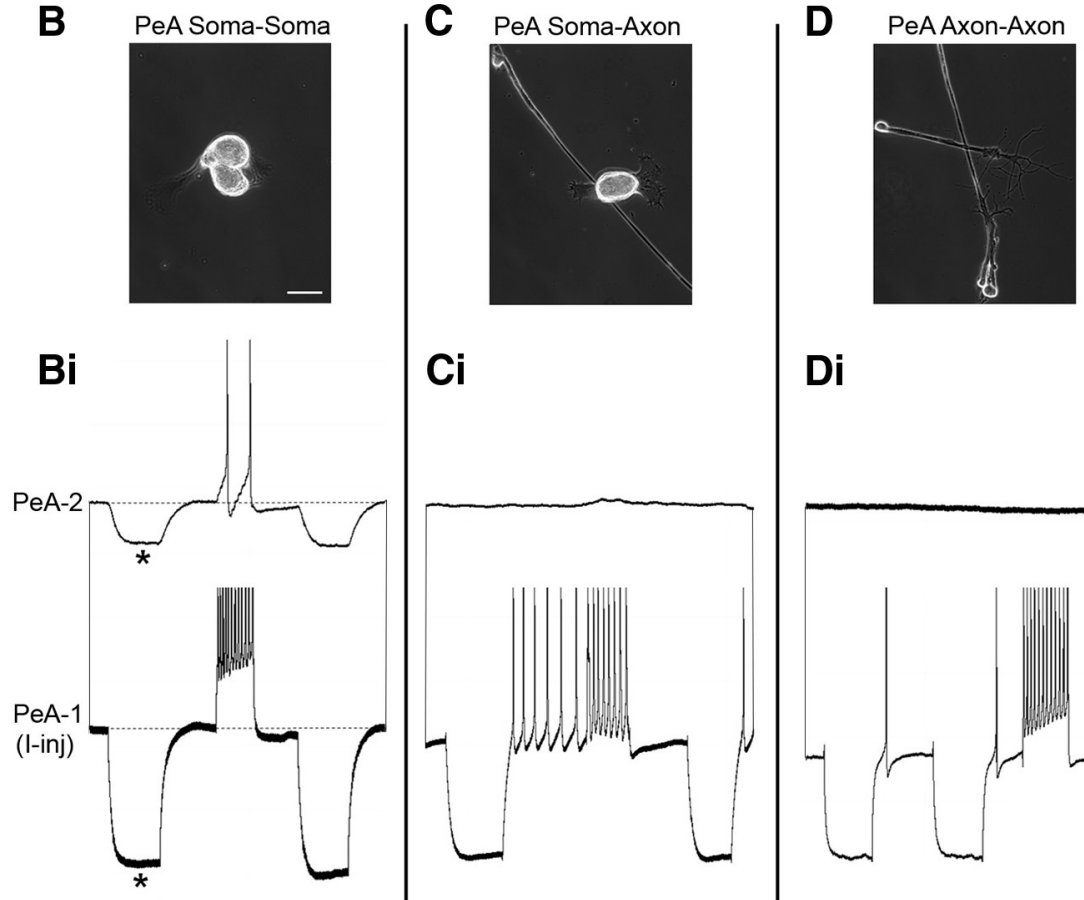

Di
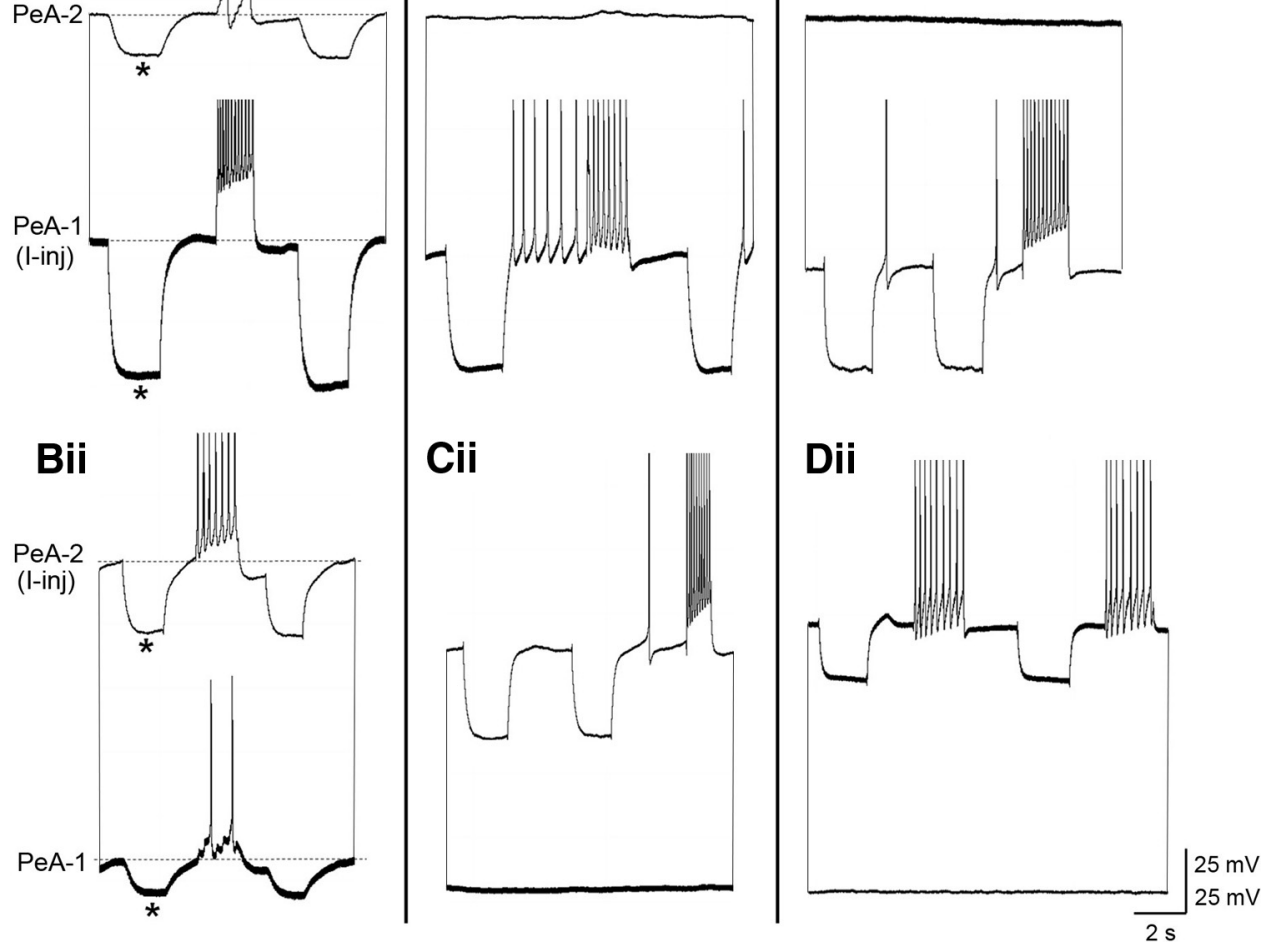

Figure 1. The development of electrical coupling between Lymnaea neurons requires the presence of both somata. $\boldsymbol{A}$, Schematic diagrams depicting the ganglionic location and synaptic connections between identified Lymnaea neurons used in this study. Specifically, the PeA cluster cells in vivo form electrical synapses with both ipsilateral and contralateral counterparts. The VD4 (presynaptic) and the LPeD1 (postsynaptic) cells in vivo form chemical synapses. To study electrically synapses, PeA neurons were isolated and cultured in Lymnaea brain CM in a soma-soma (B), soma-axon $(\boldsymbol{C})$, and axon-axon $(\boldsymbol{D})$ configuration for $20-24 \mathrm{~h}$. Scale bar, $50 \mu \mathrm{m}$. Sharp electrode recordings were conducted to verify the development of electrical synapses, and representative traces of different culturing configurations are shown in Bi-ii (soma-soma), Ci-ii (soma-axon), and Di-ii (axon-axon). To test for electrical coupling, square pulses of hyperpolarizing or depolarizing currents (amplitude of 0.1-0.3 nA, duration of 2-3 s) were injected in one cell, and the induced changes in membrane potentials of both the injected and the noninjected cells were monitored (action potentials truncated). Current injection (I-inj) in PeA-1-induced synchronous voltage change in both PeA-1 itself and the noninjected PeA-2 (Bi). Similarly, I-inj in PeA-2 induced voltage change of PeA-1, indicating the presence of bidirectional coupling between PeA somata. However, there was no electrical coupling observed in either the soma-axon (Ci-ii) or axon-axon (Di-ii) pairs, where I-inj in either cells failed to trigger changes in membrane potential of the noninjected cells. Dotted lines indicate the baseline membrane potentials. ${ }^{*}$ Concurrent changes in membrane potentials.

synapse formation was determined using Pearson's $\chi^{2}$ test with SPSS Statistics 21 for Windows. The overall significance of the percentage of cells exhibiting synapse formation among multiple groups were first determined by an omnibus Pearson's $\chi^{2}$ test. The significance between each pair of treatments was then determined using individ- ual Pearson's $\chi^{2}$ tests. The differences in the mean values of the electrical coupling coefficient, synaptic strength, and short-term potentiation between two groups were analyzed using an unpaired Student's $t$ test. Values were considered statistically significant at the level of $p<0.05$. 


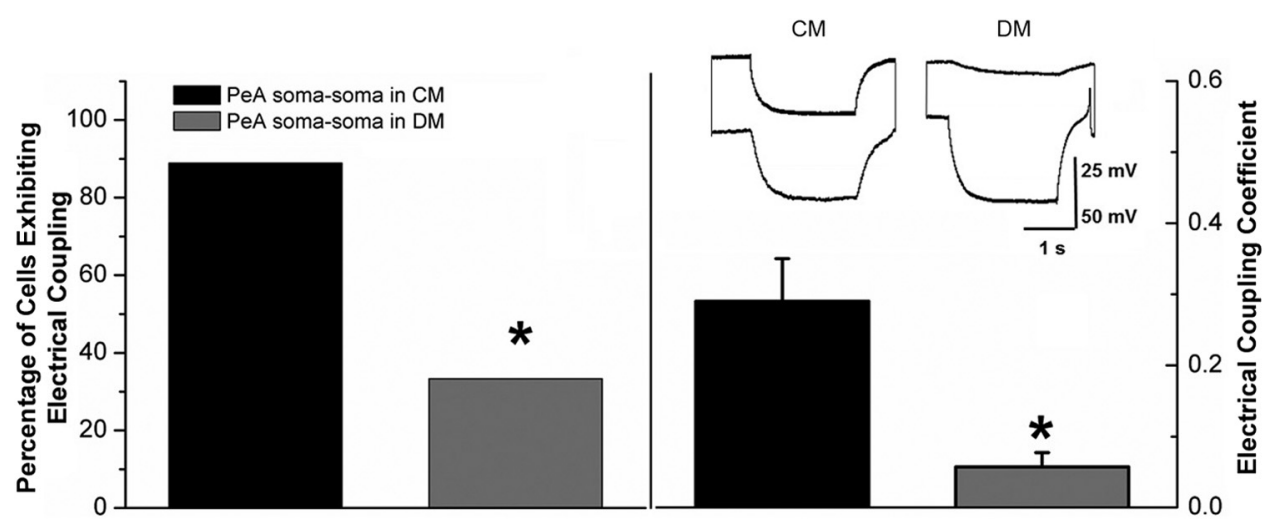

Figure 2. The formation of electrical coupling is contingent upon extrinsic trophic factors in CM. PeA neurons were juxtaposed in a soma-soma configuration and cultured in CM (contains trophic factors) and defined medium (DM, does not contain trophic factors) for $\sim 24 \mathrm{~h}$. The incidence of electrical synapse formation (left) and the coupling coefficient (right) were determined with intracellular recordings. The coupling coefficient was determined by the ratio of voltage change $(\Delta \mathrm{mV})$ in the noninjected cell over the voltage change in the injected cell, and a mean coupling coefficient of bidirectional data was acquired from each pair. It showed that the incidence of electrical coupling and the coupling strength were both significantly enhanced by $\mathrm{CM}(n=8$ of 9$)$ compared with DM $(n=3$ of 9$)$. Data are mean \pm SEM. ${ }^{*} p<0.05$.

\section{Results}

Electrical synapse formation requires intact presynaptic and postsynaptic somata and is contingent upon extrinsic trophic factors

Both presynaptic and postsynaptic chemical synaptic partners possess preassembled synaptic machinery before contact (Chow and Poo, 1982, 1985; Shapira et al., 2003; Gerrow et al., 2006). As such, synaptic pairs can initiate synaptogenesis immediately after contact (Munno and Syed, 2003). Similar evidence for electrical synapses, however, is lacking. Specifically, the innate propensity of the extrasomal compartment to initiate and form electrical synapses, independent of the cell body, is lacking. In this study, we first sought to determine whether electrical coupling could develop at extrasomal sites when the nuclear transcription factors in either one or both somata was absent. Specifically, Lymnaea PeA cells were isolated, which form electrical synapses in vivo (Kyriakides et al., 1989), and juxtaposed in Lymnaea CM (contains trophic factors) in a soma-soma, soma-axon (removal of one soma), and axon-axon (removal of both somata) configuration as shown in Figure 1. We have previously demonstrated that proper excitatory, chemical synapses reestablish in both somasoma and soma-axon (removal of one soma) configurations when neurons are paired in CM (Meems et al., 2003). Here, we postulated that cells that were normally electrically coupled in vivo would re-form their electrical synapses in vitro in both somasoma and soma-axon configurations.

To test the above prediction, intracellular recordings from the two PeA cells were made after $20-24 \mathrm{~h}$ in culture, and evidence for electrical coupling was determined via intracellular recordings. We found that, when PeA cells were cultured in a somasoma configuration, injection of hyperpolarizing currents into the PeA-1 cell (Fig. $1 B i$, bottom trace) caused a corresponding hyperpolarization in the noninjected PeA-2 cell (Fig. 1Bi, top, indicated by asterisks); the baseline membrane potentials are indicated by a dotted line. In addition, depolarizing current pulses triggered action potentials in PeA-1, which generated synchronous membrane depolarization and firing of action potentials in PeA-2. Likewise, injection of hyperpolarizing or depolarizing currents in PeA-2 cells induced concurrent potential changes in PeA-1 cells (Fig. 1Bii), indicating the presence of bidirectional electrical coupling between PeA somata. Bidirectional electrical synapses were observed in $89 \%$ of soma-soma pairs $(n=9)$ examined in CM. Interestingly, contrary to our prediction, the percentage of electrical coupling in soma-axon pairs was significantly reduced to $14 \%\left(\chi^{2}(1)=8.905, p=0.003\right)$. Injection of current into either the soma (Fig. 1Ci) or axon (Fig. 1Cii) did not elicit any corresponding changes in membrane potential of the noninjected partner, although very weak coupling was detected in one of the pairs. Consistent with our earlier predictions, electrical coupling was absent when both somata were removed in all the axon-axon cultures (Fig. $1 D i, D i i, n=6$ ). Together, these data suggest that the development of electrical coupling requires gene transcription regulation in both somata and that one intact soma is insufficient to enable formation of electrical synapses between the cell body and an isolated axon.

We next asked whether the formation of electrical synapses required extrinsic trophic factors. Specifically, we wanted to determine whether isolated somata alone were sufficient to induce electrical coupling between pairs of PeA cells. To address this, PeA neurons were cultured in a soma-soma configuration in the presence of CM (contains trophic factors) or DM (does not contain trophic factors) for $24 \mathrm{~h}$ and synapses were verified with intracellular recordings. Our results demonstrate that, when cultured in CM, strong electrical coupling develops in $89 \%$ of somasoma pairs $(n=9)$, whereas only $33 \%$ of pairs $(n=9)$ exhibited electrical coupling when cultured in DM (Fig. 2, left). The incidence of electrical coupling in DM was significantly reduced compared with $\mathrm{CM}\left(\chi^{2}(1)=5.844, p=0.016\right)$. To determine whether the strength of electrical coupling exhibited by the cells paired in DM was comparable with that in CM, an electrical coupling coefficient was measured according to the protocol established by Szabo et al. (2004). Specifically, the ratio of membrane potential change (measured at the peak membrane hyperpolarization) in noncurrent injected cells to that in current-injected cells was calculated, and a single mean coupling coefficient was determined by averaging bidirectional data from each pair. An unpaired Student's $t$ test revealed that the mean coefficient of soma-soma coupling in $\mathrm{CM}(0.29 \pm 0.06 ; n=8)$ was significantly reduced to $0.06 \pm$ 0.02 in DM $(n=3 ; p=0.011)$ in neurons that still formed electrical coupling (Fig. 2, right). These data indicate that trophic factors indeed play essential roles in the incidence and strength of electrical coupling. 
Excitatory chemical synapses formed between soma-soma and soma-axon cell pairs exhibit similar efficacy of synaptic transmission, synaptic plasticity, and temporal patterns of connectivity

Previous studies have shown that, for excitatory chemical synapse to form, the presynaptic but not the postsynaptic cell body is required between soma-axon pairs (Meems et al., 2003). However, a precise quantitative measurement comparing the efficacy of synaptic strength and plasticity has not been conducted. To determine the capacity for an isolated axon to support synaptic transmission and short-term plasticity, we compared synaptic parameters, including the incidence of synapse formation, efficacy of synaptic transmission, and synaptic plasticity between the soma-soma and somaaxon pairs. To do this, the presynaptic VD4 soma was juxtaposed either with postsynaptic LPeD1 soma or the isolated axon severed from its cell body (Fig. 3A) and cultured overnight (16-18 h) in CM. Intracellular recordings from both presynaptic and postsynaptic cells were conducted the next day. A representative trace of a VD4 soma and isolated LPeD1 axon recording is shown in Figure $3 B$. All soma-soma pairs ( $100 \%$; $n=13$ ) re-formed their proper connections, whereas $86 \%$ of soma-axon pairs $(n=14)$ established excitatory synapses in CM. Statistical analysis revealed no significant difference in the incidence of synapse formation $\left(\chi^{2}(1)=\right.$ $2.006, p=0.157)$. An unpaired Student's $t$ test also revealed no significant difference $(p=0.849)$ in the mean amplitude of EPSPs recorded from the soma-soma $(10.75 \pm 1.59 \mathrm{mV} ; n=13)$ and somaaxon (10.21 $\pm 2.28 \mathrm{mV} ; n=12)$ pairs (Fig. 3C). Next, as shown in Figure 3B, the single action potential fired after the tetanus (pEPSP) in VD4 was potentiated compared with the EPSP measured before tetanic stimulation (indicated by a dotted line). These data show that the well-characterized short-term synaptic plasticity (termed post-tetanic potentiation) seen in soma-soma pairs (Luk et al., 2011) was also preserved in the soma-axon configuration. The ratio of pEPSP/EPSP was used to quantify post-tetanic potentiation. Statistical analysis showed no significant difference $(p=0.6972)$ in the ratio of $p E P S P / E P S P$ between soma-soma $(2.37 \pm 0.23, n=13)$ and soma-axon $(2.75 \pm 0.68, n=12)$ pairs (Fig. $3 D)$. In summary, synapses formed between soma-soma and soma-axon pairs were similar in terms of their synaptic efficacy and short-term plasticity.

To further investigate the temporal pattern of synapse formation, neurons were cultured in soma-soma and soma-axon configurations and the synaptic strength was monitored using intracellular recordings at specific time periods $(4,6,8,12,16 \mathrm{~h})$ after culture (Fig. $3 E, F$ ). Our data revealed the precise temporal patterns of connectivity between cells paired in soma-soma and
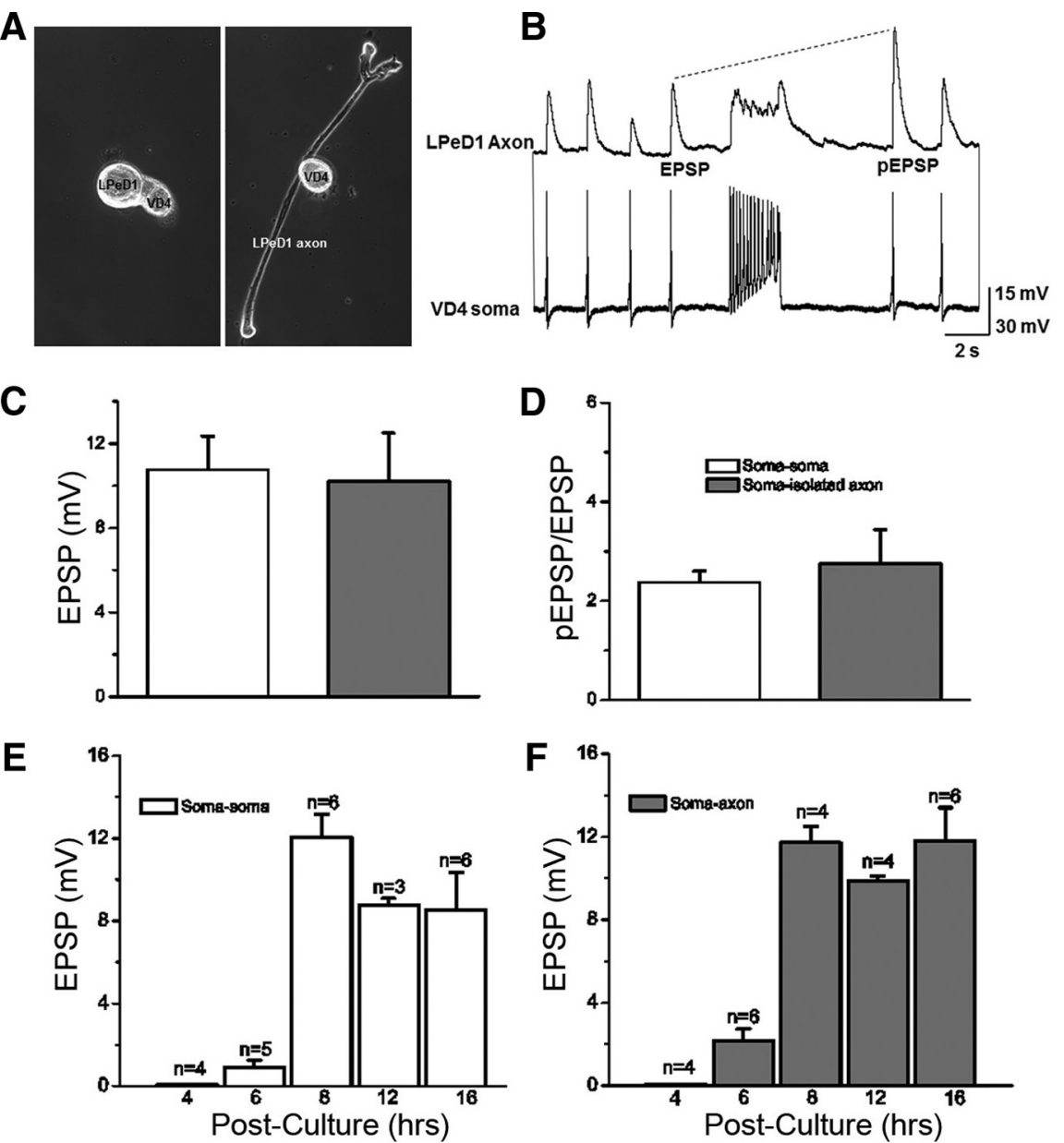

Figure 3. Chemical synapses formed in CM between soma-soma and soma-axon pairs exhibited the same synaptic efficacy, short-term plasticity, and temporal pattern of development. The presynaptic cell, VD4 (cholinergic), and its postsynaptic partner, , were juxtaposed in a soma-soma $(\boldsymbol{A}$, left) and soma-axon $(\boldsymbol{A}$, right) configuration and cultured in $(\mathrm{M}$ for $\sim 16-18 \mathrm{~h}$. Scale stimulation (termed post-tetanic potentiation), was also preserved in soma-axon pairs (indicated by the dotted line) The synaptic strength ( $\boldsymbol{C}$, indicated by the mean amplitude of EPSPs) and the post-tetanic potentiation ( $\boldsymbol{D}$, indicated by the ratio of pEPSP/EPSP) showed no significant difference between soma-soma and soma-axon pairs ( $p>0.05)$. Next, to test the temporal pattern of synation in soma-soma and soma-axon cultures, cells were paired in CM and, after specific time points $(4,8,12$, and $16 \mathrm{~h}$ ), were recorded intracellularly. The trend of synapse formation over a $16 \mathrm{~h}$ timeline was similar between the different culture configurations (E, soma-soma; $\boldsymbol{F}$, soma-axon).

soma-axon configurations. Specifically, within $4 \mathrm{~h}$ of culturing, there were no detectable synapses in either soma-soma $(n=4)$ or soma-axon $(n=4)$ configurations. After $6 \mathrm{~h}$ in culture, the mean amplitude of EPSPs measured in soma-soma pairs was $0.91 \pm$ $0.34 \mathrm{mV}(n=5)$ and $2.16 \pm 0.57 \mathrm{mV}$ in soma-axon pairs $(n=6)$. However, after $8 \mathrm{~h}$ in culture, the mean EPSP amplitude appeared to reach a plateau, indicating that the synapses had fully matured in both configurations. Specifically, the EPSP amplitude of soma-soma synapses at $8 \mathrm{~h}$ was $12.04 \pm 1.14 \mathrm{mV}(n=6)$ and $11.7 \pm 0.8 \mathrm{mV}(n=4)$ in the soma-axon pairs. The newly established synapses were then maintained for $12 \mathrm{~h}(8.75 \pm 0.34 \mathrm{mV}$, $n=3$, soma-soma; $9.88 \pm 0.23, n=4$, soma-axon) and $16 \mathrm{~h}$ $(8.52 \pm 1.82 \mathrm{mV}, n=6$, soma-soma; $11.81 \pm 1.59 \mathrm{mV}, n=6$, soma-axon) under both culture conditions (Fig. $3 E, F$ ). Statistical analysis revealed no significant difference between somasoma and soma-axon groups at each time point. Together, these data demonstrate that the isolated LPeD1 axon is capable of supporting synapse formation, synaptic transmission, and short- 
A
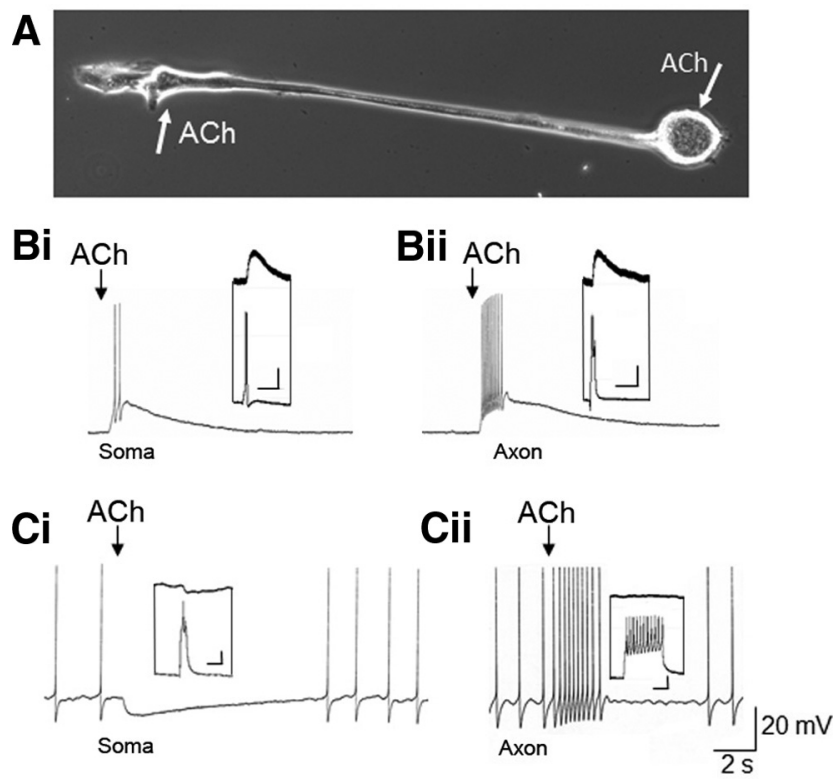

Figure 4. Trophic factors were required for excitatory synaptogenesis between soma-axon pairs. To determine whether soma-axon synaptogenesis requires trophic factors, VD4 and LPeD1 were cultured either in CM or DM in soma-soma and soma-axon configuration. Intracellular recordings revealed that proper excitatory synapses were established in both somasoma (Bi, inset) and soma-axon (Bii, inset) in CM (horizontal bar represents $0.5 \mathrm{~s}$, vertical bar represents $7.5 \mathrm{mV}$ for the top trace and $15 \mathrm{mV}$ for the bottom trace). In DM, the "default" (not seen in vivo) inhibitory synapse was developed between soma-soma pairs ( $\boldsymbol{C}$, inset; horizontal bar represents $0.5 \mathrm{~s}$, vertical bar represents $7 \mathrm{mV}$ ), whereas neither inhibitory nor excitatory synapses were detected in soma-axon pairs (Cii, inset; horizontal bar represents $0.5 \mathrm{~s}$, vertical bar represents $5 \mathrm{mV}$ for the top trace and $20 \mathrm{mV}$ for the bottom trace). To test whether the failure of synapse formation between soma-axon pairs in DM resulted from the lack of functional $n A C h R s$ in the axon, intact LPeD1 neurons were cultured either in CM or DM, and the effect of exogenously applied $\mathrm{ACh}(1 \mu \mathrm{m})$ at the soma and at the axon was tested. Scale bar: $A, 50 \mu \mathrm{m}$. The results showed that $L P e D 1$ axons responded to exogenous $A C h$ by exhibiting an excitatory response regardless of being cultured in CM (Bii) or DM (Cii), whereas the LPeD1 cell body exhibited excitatory (Bi) in $\mathbf{C M}$ and inhibitory responses in DM ( $(\boldsymbol{C})$. These data indicate that nAChRs are expressed in LPeD1 axon in DM, and their redistribution and aggregation at the contact site for the development of a functional synapse depend on the presence of $\mathrm{CM}$.

term plasticity at a time course that is analogous to that of the intact LPeD1 soma.

\section{Trophic factors are required for excitatory cholinergic synapse formation between soma-soma and soma-isolated axon pairs}

The above data clearly demonstrate that, in the presence of CM, the incidence and efficacy of excitatory, chemical synapses were maintained under soma-soma and soma-axon culture conditions. Next, to determine whether the soma-isolated axon pairs require trophic factors, they were cultured either in the presence or absence of CM. It is important to note that, in the absence of $\mathrm{CM}$ (and other trophic factors), the soma-soma paired VD4LPeD1 develop an inappropriate inhibitory, cholinergic synapse (does not exist in vivo or between neurite-neurite synapses), termed the "default" inhibitory synapse (Munno et al., 2000). An example of such an "inappropriate" inhibitory, default synapse in DM is depicted in Figure 4Ci (inset), whereas proper excitatory chemical synapses form in $\mathrm{CM}$ (Fig. $4 B i$, inset). To test whether VD4-LPeD1 synapses paired in a soma-axon configuration exhibited a similar trophic factor dependence, VD4 soma and LPeD1- isolated axon were cultured either in the absence or presence of CM. We found that $100 \%$ of soma-soma (Fig. $4 B i$, inset, $n=16$ ) and $90 \%$ of soma-axon (Fig. $4 B i i$, inset, $n=32$ ) pairs developed excitatory synapses in CM. As expected, when somasoma synapses were cultured in DM, action potentials triggered an IPSP in LPeD1 soma, indicating an inhibitory synapse between the two cells (Fig. 4Ci, inset, $n=9$ ). However, when somaaxon pairs were cultured in DM, neither excitatory nor inappropriate inhibitory synapses developed in $88 \%$ of pairs $(n=$ $25)$; a train of action potentials in VD4 failed to trigger any response in $\mathrm{LPeD} 1$ axons (Fig. 4 Cii, inset), with the remaining $12 \%$ pairs ( $n=$ 25 ) forming weak excitatory synapses. The percentage of soma-axon pairs that formed excitatory synapses in DM was significantly reduced compared with that in $\mathrm{CM}\left(\chi^{2}(1)=35.037, p<0.001\right)$. Similar results were seen in a previous study conducted, showing the importance of trophic factors in the formation of excitatory synapses in soma-axon pairs (Meems et al., 2003).

To test whether this lack of synaptic response in DM-cultured soma-axon pairs was due to the absence of either excitatory or inhibitory nAChRs, we performed intracellular recordings on the isolated axons while pressure applying ACh $(1 \mu \mathrm{M})$. We found that all isolated axons cultured in CM (Fig. 4Bii; $n=21$ ), regardless of their pairing conditions (single or paired), exhibited an excitatory response in a manner analogous to that of its somata (Fig. $4 \mathrm{Bi}$; $n=14$ ). However, $\mathrm{ACh}$ elicited different responses in $\mathrm{LPeD} 1$ somata and the isolated axons when cultured in DM (Fig. 4Ci,Cii). Specifically, in DM, ACh elicited inhibitory responses in the somata of all neurons $(n=8$; Fig. 4Ci). Interestingly, axons from the same neurons exhibited excitatory responses $(n=8$; Fig. 4Cii) as the applied ACh triggered action potentials in DM, indicating the presence of excitatory nAChRs. These data, on the one hand, demonstrate that, although the LPeD1 cell body expresses both inhibitory and excitatory receptors, the former are confined exclusively to the somata and were not functionally targeted to the extrasomal compartments. On the other hand, our data show that in the absence of trophic factors, postsynaptic cell contact-based signaling is insufficient for targeting excitatory nAChR to the soma-axon contact sites to allow for the assembly of functional synapses.

\section{A limited pool of nAChRs is present throughout the postsynaptic axon and target-cell contact redirects receptors to the specific synaptic site in the presence of trophic factors} Our data demonstrate that both target cell contact and extrinsic trophic factors are required for excitatory synapse formation between VD4 somata and the isolated axon from LPeD1. We have also shown that isolated $\mathrm{LPeD} 1$ axons express excitatory nAChRs, even in the absence of trophic support (DM; Fig. 4Cii). Based on these observations, we hypothesized that a pool of nAChRs is distributed throughout the entire length of LPeD1 axon and that trophic factors may enable target-cell contact signaling to invoke their redistribution from extrasynaptic to synaptic sites. To test this hypothesis, we severed a single LPeD1 axon into two halves and then evaluated the responsiveness of each segment to exogenous ACh after overnight $\mathrm{CM}$ incubation. On the second day, exogenous $\mathrm{ACh}$ was pressure applied on each of the two segments. Both segments exhibited similar responses to the exogenous application of ACh $(n=6)$ (Fig. $5 A, B)$, suggesting an even distribution of AChR pool in each axonal segment. We next tested whether each severed half of LPeD1 segment was capable of forming an excitatory synapse with its respectively paired VD4 cell. Each severed half was paired with its corresponding VD4 neuron and cultured overnight to allow for synapse formation. Interestingly, we found that, in $53 \%$ of pairs $(n=$ $15)$, neither compartment could form an electrophysiologically detectable synapse (Fig. $5 C$ ). In $15 \%$ of pairs $(n=15)$, only one axon formed a synapse. We did, however, find that, in $33 \%$ of pairs $(n=$ 15), both compartments formed synapses, although the synaptic 


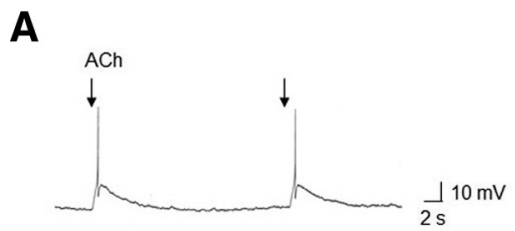

B
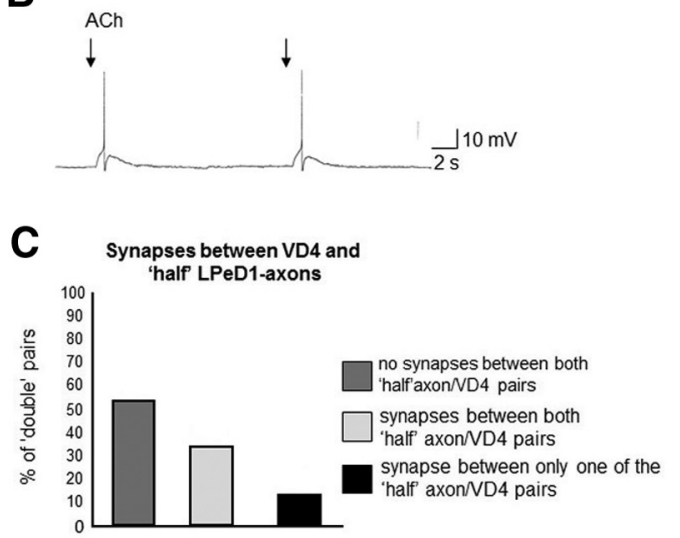

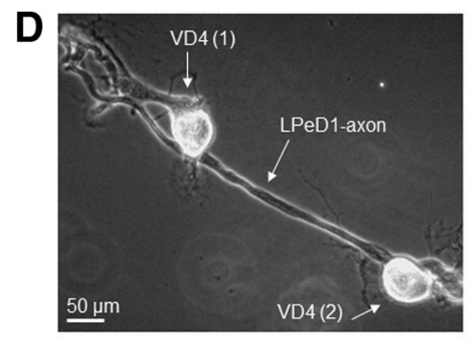

E

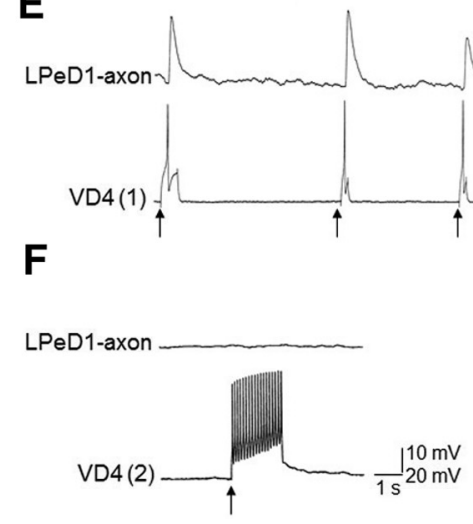

Figure 5. Target cell contact directs limited nAChR to the contact site, but only one presynaptic VD4 cell can develop effective synaptic transmission. We first tested whether cholinergic receptors were expressed throughout the LPeD1 axon. To test this, the LPeD1 axon was transected in the middle and cultured in CM overnight. We determined whether LPeD1-axons severed in two halves still responded to ACh through local application of $1 \mu \mathrm{m} A C h$ to each half. We found that $A C h$ was able to evoke excitatory responses in both halves, resulting in action potentials $(A, B)$. Furthermore, the excitatory responses from both segments appeared similar, suggesting an even distribution of AChRs throughout the LPeD1-axon. We next tested whether both severed segments would form synapses with two VD4s. C, Data showed that 8 of 15 soma/axon-segment pairs did not develop synapses. In 5 of 15 preparations, weak excitatory synapses were formed between both soma/axon-segment pairs, and in 2 of 15 preparations one soma/axonsegment developed a synapse, whereas the other soma/axon-segment did not. These data suggest that the two halves of the severed axons could develop synapses with VD4 paired in each segment. However, the incidence of synapse formation and synaptic strength was greatly reduced, indicating that the finite pool of receptors in each of the severed segment of the axon may have been insufficient for synapse formation. To test whether a full-length of LPeD1 axons could form synapses with 2VD4s, (D) single LPeD1-axons were cultured in CM and paired with a VD4 at either end of the axon. After 18 -24h, intracellular recordings demonstrated that, if the axon had developed a synapse with one VD4 $(\boldsymbol{E})$, synapses failed to develop between the axon and the second VD4 $(\boldsymbol{F})$. These data further indicated that a limited number of receptors are likely present in the axon and are not sufficient to support effective synaptic transmission with multiple targets.

strength of each was reduced compared with the full axon (Fig. 5C). Thus, a single axon severed in two "halves" permits innervation by two VD4s, but with reduced consistency of synapse formation and synaptic efficacy, indicating that there likely exists a finite number of nAChRs in the receptor pool of each segment in the absence of the cell body.

Next, we examined whether receptors across the entire length of the isolated LPeD1 axon could form multiple synapses with supernumerary target cells. A single isolated LPeD1 axon was simultaneously paired with two VD4s (Fig. 5D) and cultured in $\mathrm{CM}$ overnight. Intracellular recordings were made from both VD4s and the axon the next day. We found that, in all instances $(n=6)$, LPeD1 axons only supported synapse formation with one VD4, whereby induced action potentials in one VD4 elicited 1:1 EPSPs (Fig. 5E), whereas triggered activity in the second VD4 failed to generate any detectable response in the LPeD1 axon despite physical contact (Fig. 5F; $n=6$ ). These results suggest that even a full-length axon expresses a limited number of receptors and, as such, could afford innervation with only one presynaptic target cell for formation of an effective synapse.

Transmitter-receptor interactions between VD4 somata and LPeD1 axons are required for a functional lateral migration of nAChR from extrasynaptic to the synaptic/contact site

Despite limited numbers, receptors located on the isolated axons selectively aggregate to one contact site to form a solitary effective synapse. However, the precise signaling pathway(s) involved in invoking receptor clustering to the contact site remain elusive.
Previous studies have demonstrated that, in the course of synapse formation, target-cell contact induces transmitter release (Xie and Poo, 1986; Zhang and Poo, 2002) and causes redistribution of receptors from the extrasynaptic to synaptic site (Meems et al., 2003). However, it remains unclear whether the released transmitter from the target cell is indeed responsible for clustering postsynaptic receptors required for effective synapse formation. To this end, we first sought to test whether a presynaptic nontarget cell (lacking release of $\mathrm{ACh}$ ) could similarly induce receptor clustering in the isolated LPeD1 axons in the presence of trophic factors. We paired isolated LPeD1 axons with a nontarget cell, visceral $\mathrm{F}$ (VF). VF expresses the neurotransmitter peptide FMRFamide (Bright et al., 1993) and is located in the vicinity of VD4 with overlapping neuritic arbors but does not form a synapse with LPeD1 in vivo. We found that, in all instances $(n=6)$, VF did not form a synapse with isolated LPeD1 axons (Fig. 6A, inset). Specifically, induced action potentials in VF did not trigger postsynaptic responses in LPeD1 axons (Fig. 6A, inset). When ACh was applied locally to the axon, we found that there was a stronger response in the "extrasynaptic" regions (Fig. $6 B$ ) versus the VF contact site (Fig. 6A). These results suggest that nonsynaptic partners do not induce the redistribution of nAChRs to the contact site.

The above finding suggested that membrane contact or other second messenger signaling cascades evoked in the postsynaptic neuron are not sufficient to induce $\mathrm{nAChR}$ clustering. We next sought to determine whether ACh release from VD4 is directly responsible for receptor clustering at the contact site by 


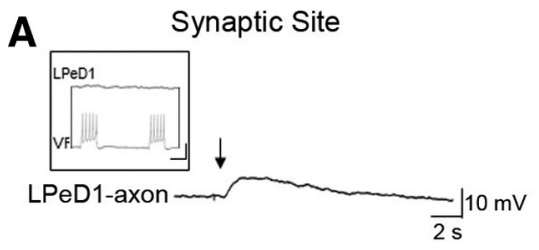

B

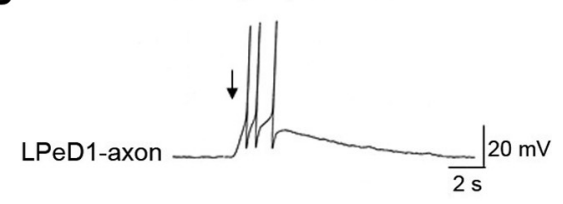

C Soma-Axon Pair in HMC

D ACh Puff on Axon of Soma-Axon Pair
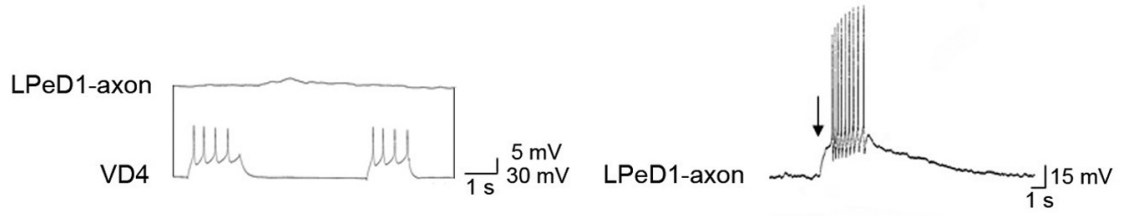

Figure 6. The target cell but not nontarget cell induced redistribution of receptors to contact sites and blocking transmitterreceptor interactions prevented excitatory synapse formation between soma-axon pairs. Pairing LPeD1 axon with a nontarget cell, the VF soma, in CM did not result in excitatory synapse formation ( $\boldsymbol{A}$, inset; horizontal bar represents $1 \mathrm{~s}$, vertical bar represents $10 \mathrm{mV}$ for LPeD1 axon and $20 \mathrm{mV}$ for VF). Specifically, a burst of action potentials in VF failed to produce an excitatory response in LPeD1 axon. Under these experimental conditions, $(\boldsymbol{A})$ ACh application at the contact site produced small depolarizing responses, $(B)$ whereas ACh generated action potentials at the extrasynaptic site $(n=6)$. To test the importance of AChR activation in excitatory synapse formation, soma-axon pairs were cultured in the presence of the AChR antagonist hexamethonium chloride (HMC, $100 \mu \mathrm{M})$. C, Intracellular recordings showed that excitatory synapses failed to develop in the presence of hexmethonium, whereas $(\boldsymbol{D})$ the LPeD1-axon still responded with an excitatory response to exogenously applied ACh $(1 \mu \mathrm{M})$.

blocking transmitter-receptor interactions between soma-axon pairs. To this end, soma-axon pairs were cultured in CM either in the presence or the absence of the $\mathrm{nAChR}$ antagonist, hexamethonium chloride $(100 \mu \mathrm{M})$. After $18-24 \mathrm{~h}$ of culture, the medium containing the antagonist was substituted with fresh CM solution and synapses were tested. All pairs maintained in CM developed normal synapses as described above $(n=10,100 \%)$, whereas only $27 \%$ of the pairs cultured in CM-containing hexamethonium chloride developed excitatory synapses (Fig. $6 C ; n=$ $11)$, which was significantly reduced $\left(\chi^{2}(1)=11.748, p=\right.$ $0.001)$. To rule out the possibility that the absence of excitatory synaptic transmission was due to irreversible antagonism of cholinergic receptors by the antagonists, ACh was exogenously applied to the axons and its response tested. Pressure application of ACh $(1 \mu \mathrm{M})$ directly to the axons induced an appropriate excitatory response in all axons tested $(n=7)$ (Fig. $6 D)$, ruling out the possibility that the lack of $\mathrm{ACh}$ responsiveness was due to changes in axonal responsiveness resulting from chronic antagonist presence. These data thus suggest that, when transmitter-receptor interactions are perturbed with a reversible antagonist, receptors fail to functionally migrate to the synaptic site.

\section{nAChR internalization and protein kinase $\mathrm{C}(\mathrm{PKC})$ activity are important for target cell contact-induced receptor redistribution and excitatory synapse formation between VD4 soma and isolated LPeD1 axons}

We have shown above that $\mathrm{nAChR}$ activation by ACh release from VD4 is important for their localization from the noncontact to contact site and that blocking transmitter-receptor interactions prevents this redistribution. Considering the fact that there exists a limited pool of receptors across the length of the axon and nAChRs are specifically targeted to one developing synaptic site when challenged with supernumerary targets (Fig. 5), we postulated that the receptor redistribution from the noncontact to contact sites most likely involves receptor internalization and the lateral migration of receptors across the entire length of the axon. Consistent with this postulate are other findings reported in literature (Broadie and Bate, 1993; Berry et al., 1996; Bhattacharyya et al., 2002; Fan et al., 2004; Rasse et al., 2005). Based on the observation that synapse formation between VD4 and LPeD1 axons depends on receptors already present on the surface of severed axonal segments, we hypothesized that the process of receptor internalization (through endocytosis) and lateral migration to the contact site may be involved in trophic factor-mediated synapse formation. To test this hypothesis, we cultured VD4 soma and isolated LPeD1 axon pairs overnight in $\mathrm{CM}$ alone (as a control) or CM containing Dynasore, a selective inhibitor of dynamin GTPase activity required for clathrin-dependent endocytosis. The incidence of synapse formation and the postsynaptic response to exogenous ACh were tested the next day after the removal of the drug. Our data showed that $20 \mu \mathrm{M}$ Dynasore prevented synapse formation in all VD4 and LPeD1 axon pairs $(n=6)$. As shown in Figure 7, all control pairs (Fig. $7 A$, inset; $n=6$ ) exhibited robust excitatory synapses where action potentials triggered 1:1 EPSPs in LPeD1 axons. However, when synaptic pairs were cultured in Dynasore, action potentials failed to generate postsynaptic responses (Fig. $7 B$, inset; $n=7$ ). In addition, local application of ACh revealed a stronger response at the extrasynaptic site than at the synaptic sites in $71 \%$ of LPeD1 axons (Fig. $7 B$ ). In $29 \%$ of trials, equal but weak responses were detected in both the synaptic and extrasynaptic sites, whereas all LPeD1 axons exhibited a stronger response at the synaptic sites than at the extrasynaptic sites when cultured in CM alone (Fig. 7A; $n=$ $6)$. These results clearly demonstrate that receptor internalization and redistribution to the contact site are a crucial step involved in postsynaptic development during trophic factor-dependent excitatory synapse formation.

In many reported cases, receptor internalization, trafficking, and aggregation to the synaptic sites depend on a protein phosphorylation process specifically mediated by the activity of PKC (Bhattacharyya et al., 2002; Mundell et al., 2002; Chou et al., 2010). To determine the role of PKC in cholinergic synapse formation between the soma-axon pairs, VD4/LPeD1 soma-axon pairs were cultured in $\mathrm{CM}$ either in the absence (control) or the presence of chelerythrine chloride, an inhibitor of PKC plasma membrane translocation and activation. Intracellular recordings revealed that $78.1 \%$ of control soma-axon pairs formed excitatory synapse $(n=32$; Fig. $7 E)$, whereas no excitatory synapses were observed in all pairs cultured in the presence of $0.5 \mu \mathrm{M}$ of chelerythrine $\left(\chi^{2}(1)=10.227, p=0.001, n=4\right.$; Fig. $\left.7 C, E\right)$, indicating that $\mathrm{PKC}$ activation is essential for synapse formation between soma-axon pairs. Exogenous application of ACh on LPeD1 axons cultured in chelerythrine still elicited a strong response, which was unchanged from control axons, indicating that receptors were still functional at the axonal surface (data not shown). Thus, a perturbation of PKC activity by chelerythrine may have prevented the localization of AChRs to synaptic sites. It did not, however, affect their functional response to ACh.

Next, to determine whether PKC activation in the absence of trophic factors was sufficient to induce excitatory synapse formation between VD4 and LPeD1 axons, they were cultured in CM alone, and DM containing PMA, an activator of PKC. Intracellu- 
lar recordings the next day revealed a significant difference in the incidence of synapse formation under the above culture conditions $\left(\chi^{2}(2)=16.537, p<\right.$ $0.001)$. Specifically, $87 \%$ of soma-axon pairs cultured in DM containing PMA (10 $\mu \mathrm{m})$ did not form proper excitatory synapses (Fig. $7 D ; n=7$ ). The incidence of synapse formation in DM containing PMA was significantly different from that in $\mathrm{CM}\left(\chi^{2}(1)=10.533, p=0.001\right)$, but not significantly different from that in CM-containing chelerythrine $\left(\chi^{2}(1)=\right.$ 0.629, $p=0.428$ ) (Fig. 7E). These data clearly demonstrated that PKC activation is required for soma-axon synapse formation, but activation of PKC alone in the absence of trophic factors is not sufficient for synapse formation between VD4 and LPeD1 axons, suggesting that additional trophic factor-dependent signaling pathways or molecules are necessary for postsynaptic development at chemical synapses.

\section{Discussion}

Chemical and electrical synapses are the two main modes of synaptic transmission required for most neuronal communication. Electrical synapses have been shown to exist in many brain regions of most organisms and are also considered a prerequisite for chemical synapse formation (Curtin et al., 2002; Todd et al., 2010; Pereda, 2014). However, neither the precise timing of electrical synapse formation (compared with chemical synapse which can begin immediately upon contact) nor the precise contribution of axonal versus somal signaling has been determined. In the present study, we provide the first direct evidence that the development of electrical synapses between Lymnaea neurons requires the somata of both neurons and that the formation of electrical synapses is contingent upon extrinsic trophic factors. Previous studies from our laboratory have demonstrated that both electrical and chemical synapses exhibit identical time course of synaptogenesis, and both rely upon de novo protein synthesis (Feng et al., 1997). A significant body of literature now supports the notion that axons alone are capable of de novo protein synthesis (Giuditta et al., 1991; Piper and Holt, 2004; Jung et al., 2012). However, our data demonstrate that only soma-soma and axonaxon pairs with somata attached (latter data not shown) were capable of developing electrical coupling, whereas no coupling was observed when even one cell body was missing. These findings demon-
A

"Synaptic" Site

"Extrasynaptic" Site
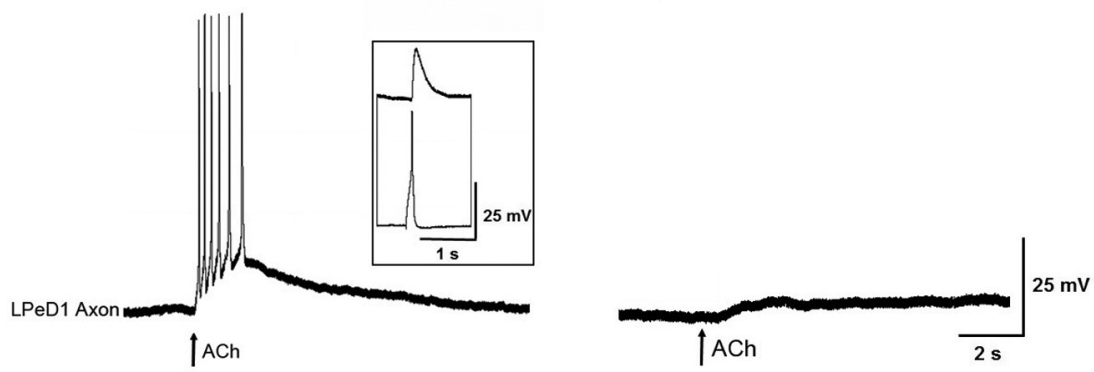

B
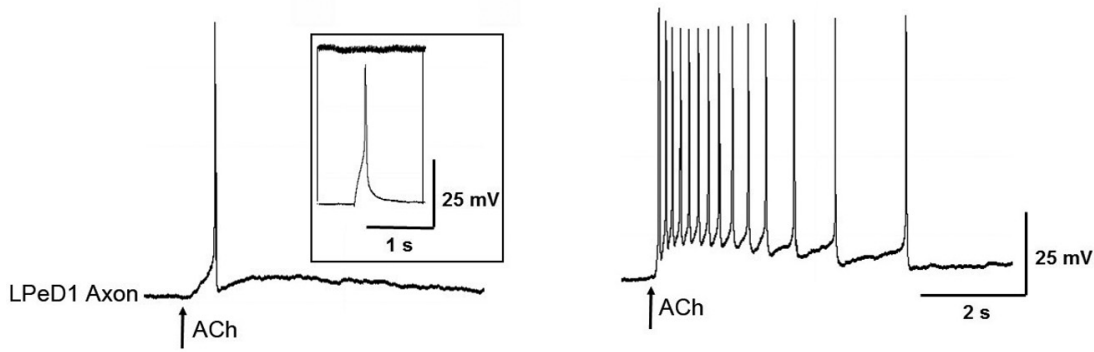

\section{C $\mathrm{CM}+$ chelerythrine}
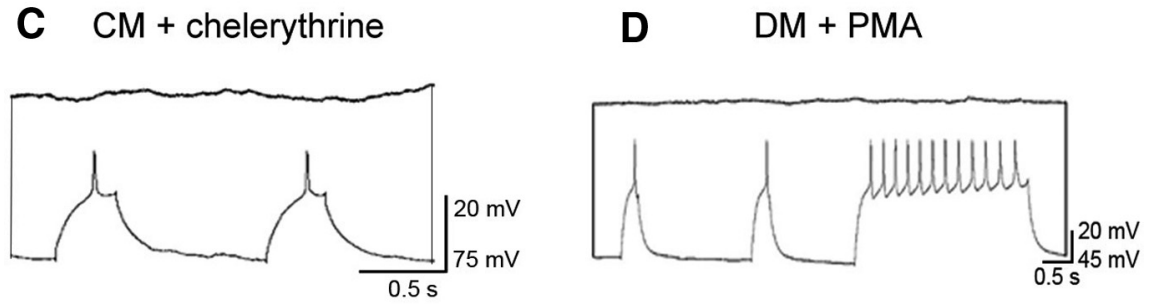

E

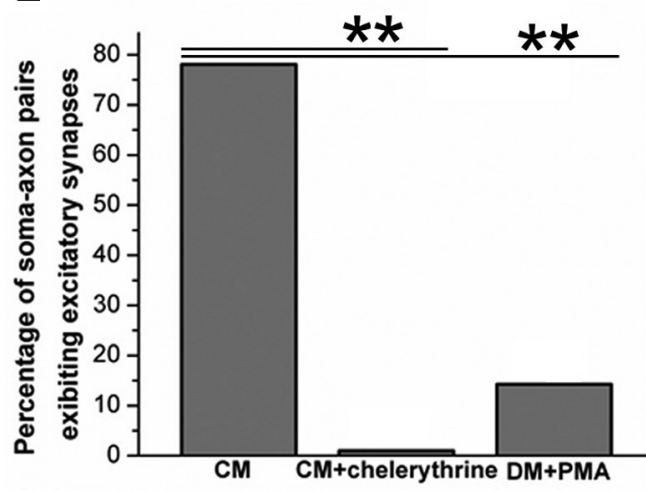

Figure 7. Blocking receptor internalization and the PKC activity inhibited synaptogenesis between soma-axon pairs. To test whether receptor internalization was involved in redistributions of $n A C h R s$ to contact sites during soma-axon synapse formation, VD4 soma and LPeD1 axon were cultured overnight in $C M$ alone $(\boldsymbol{A})$ or CM containing Dynasore $(\boldsymbol{B})$, a selective inhibitor of dynamin GTPase activity that is involved in clathrin-dependent endocytosis. The incidence of synapse formation and the postsynaptic response to exogenous ACh were tested the next day, following removal of the drug. In contrast to cells cultured in CM alone ( $\boldsymbol{A}$, inset), pairs cultured in $20 \mu \mathrm{m}$ Dynasore completely abolished synapse formation ( $\boldsymbol{B}$, inset), and application of $A C h$ elicited a stronger response at the extrasynaptic site than at the contact site $(\boldsymbol{B})$. These data indicate that the internalization of preexisting receptors is a necessary step in this redistribution to the contact site for synapse formation. To test the involvement of PKC activity in synapse formation, soma-axon pairs were cultured in CM alone, CM containing a PKC antagonist chelerythrine chloride $(0.5 \mu \mathrm{M})$, or DM containing a PKC activator PMA (10 $\mu \mathrm{M})$. Cells cultured in the presence of either chelerythrine $(\boldsymbol{C})$ or PMA (D) did not exhibit any synapse formation where action potentials in VD4 failed to elicit any responses in LPeD1 axons, whereas control cells exhibited strong synapses as shown in $\boldsymbol{A}$ (inset). $\boldsymbol{E}$, Incidence of synapse formation in the presence of chelerythrine and PMA was significantly lower compared in CM alone. ${ }^{* *} p<0.01$. 


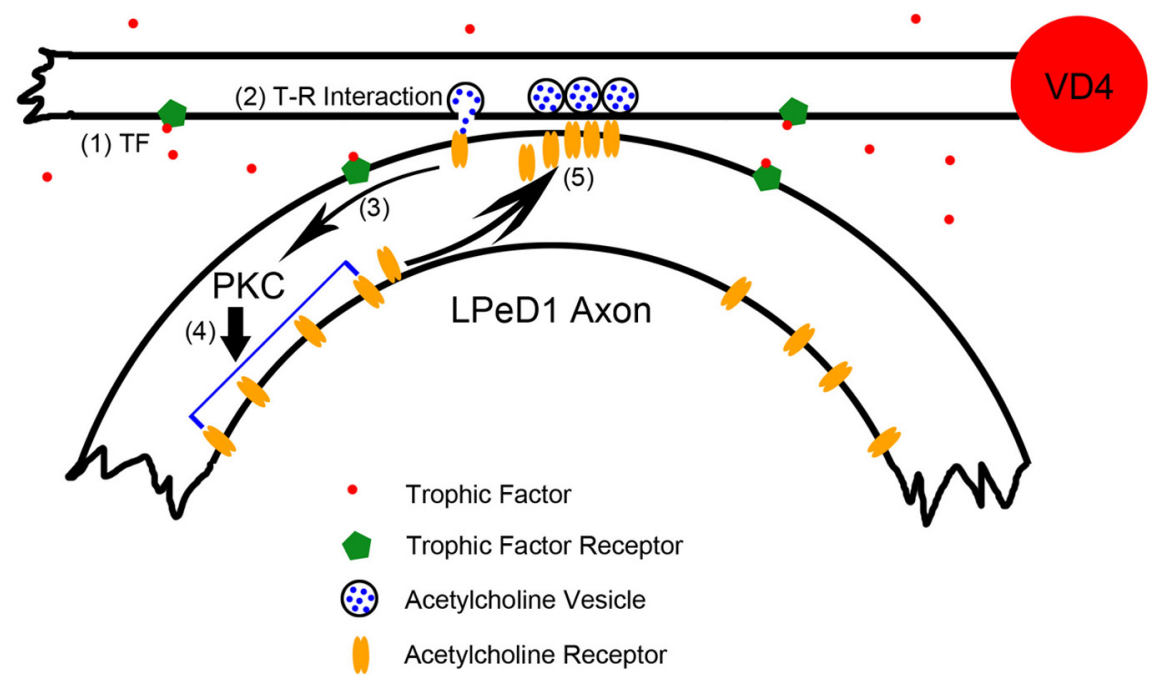

Figure 8. A schematic diagram depicting the steps involved in trophic factor-mediated chemical synapse formation between intact VD4 and the isolated LPeD1 axon. Trophic factors (red dots), acting via their respective receptors (green pentagons) located on both presynaptic and/or postsynaptic membranes, induced transmitter-receptor (T-R) interaction and the resulting activation of PKC. PKC in turn causes the internalization/redistribution of $n A C h R s$ (orange ovals) from extrasynaptic to the synaptic site.

strate, for the first time, that gap junction protein synthesis or their insertion/assembly requires the somata (i.e., gene transcription regulation) of both juxtaposed cells. It is interesting to note that when axons of PeA cluster cells are juxtaposed with their attached somata, the cells developed robust coupling, demonstrating that when somata are attached, the newly synthesized gap-junctional protein are indeed transported to extrasomal compartments and appropriately inserted in the plasma membrane. These data also suggest that perhaps both somata need to synthesize and contribute their respective complements of gapjunction proteins for proper electrical synapse development. However, further identification and characterization of Lymnaea gap junction genes and/or proteins is required to fully support this postulate.

Trophic factors are known for their role in promoting and/or controlling proliferation, differentiation, migration, survival, and outgrowth of neurons (Weisenhorn et al., 1999, Stewart et al., 2008). With recent studies, they are now well recognized as essential contributors to synapse formation and synaptic plasticity in both vertebrate and invertebrate CNSs (Park and Poo, 2013). Our data, together with other studies (Szabo et al., 2004), demonstrate that not only the formation of the excitatory chemical synapse, but also electrical coupling relies upon the presence of trophic factors. These actions of neurotrophins on growth and synaptic plasticity range from short-term modulation of ion channel activity and synaptic transmission (Rose et al., 2004; Blum and Konnerth, 2005), to long-term effects on receptor expression and synaptic plasticity that require gene transcription and de novo protein synthesis (Ying et al., 2002; Leal et al., 2014). Interestingly, here we demonstrated that an isolated axon devoid of its transcription machinery (somata) still required trophic factors to mobilize preexisting receptors from extrasynaptic to synaptic sites. Our studies thus reveal a novel role for trophic factors, which is independent of de novo protein synthesis. In the absence of the nucleus, the axon only sustained a limited number of receptors, which curbed its ability to support multiple innervations. In addition, the presynaptic target but not nontarget cell contact generated an inductive signal (likely through the release of neurotransmitter), which triggered receptor redistribution from extrasynaptic to synaptic sites in a manner analogous to that of the neuromuscular junction (Anderson and Cohen, 1977). Although peripheral neuromuscular synapses still formed when presynaptic neurotransmitter secretion was perturbed (Heeroma et al., 2003), similar evidence for central cholinergic synapses was lacking. Here we showed that blocking transmitter-receptor interactions between soma-axon pairs prevented $\mathrm{AAChR}$ redistribution in the absence of new receptor synthesis. It would have been ideal for us to label nAChRs to demonstrate their localization and redistribution patterns; however, like most central nAChRs in vertebrates, their labeling in Lymnaea has proven to be challenging (Hurst et al., 2013). Interestingly, our finding is consistent with a previous study demonstrating that chronic treatment of cultured rat spinal neurons with glycine receptor antagonist inhibited the accumulation of glycine receptors at postsynaptic sites (Kirsch and Betz, 1998). Our data thus demonstrate that, in the absence of soma-based signaling, the extrasomal compartments exhibit an innate instructive capacity to target transmitter receptors to specific contact sites. These results thus underscore the capacity of extrasomal regions to intrinsically manage receptor localization to specific synaptic sites, independent of instructive signaling from their respective somata.

It is interesting to note that target-cell contact alone was not sufficient to relocate preexisting receptors to the contact site (DM experiment, Fig. 4Bi, inset), which relied critically upon trophic factors. It can thus be argued that perhaps VD4 somata failed to release its transmitter in DM and as such synaptogenesis failed. However, this postulate cannot be supported because VD4 could still establish its inhibitory cholinergic synapses with the right pedal dorsal one (Feng et al., 1997) and a default inhibitory synapse with LPeD1. Alternatively, CM could facilitate synapse formation by increasing transmitter release from VD4. Consistent with this notion, previous studies have demonstrated that BDNF increases quantal neurotransmitter release at synaptic sites mediated by presynaptic mechanisms (Tyler and Pozzo-Miller, 2001; Zhang and Poo, 2002; Zhou et al., 2004). Similarly, mice lacking presynaptic tyrosine kinase B in the CA3 hippocampal neurons exhibit structural and electrophysiological deficits involving presynaptic neurons (Luikart et al., 2005). However, 12\% (3 of 25 pairs) of LPeD1 axons and VD4-soma pairs in DM formed excitatory synapses, demonstrating that the presynaptic secretory machinery may not be the only factor affected by CM. Treatment of central neurons with BDNF has been shown to promote the clustering of both NMDA and GABA receptors at postsynaptic terminals (Elmariah et al., 2004). In studies that demonstrated the impact of trophic factors on transmitters and their receptors, the precise sites (e.g., somal vs extrasomal) of growth factor actions have not been determined. Here, we demonstrate that growth factors could equally affect both the somata and distantly located extrasomal domains as inductive signals in promoting synapse formation between the pairs.

A novel synergistic role of trophic factor invoking transmitter-receptor interaction and subsequent receptor redistribution from extrasynaptic to synaptic sites via the activity of PKC was revealed in this study (Fig. 8). Specifically, receptors have been 
shown previously to recycle back to the cell surface after their internalization (von Zastrow and Kobilka, 1992; Naik et al., 1997; Tarasova et al., 1997; Bhattacharyya et al., 2002). At the Drosophila neuromuscular junction, extrasynaptic glutamate receptors were recruited to the newly formed synapses from a pool that was widely dispersed over the whole postsynaptic muscle cell; this involved their activation by presynaptic glutamate release (Rasse et al., 2005). Our data show a similar redistribution of existing receptors from extrasynaptic to synaptic sites at the central synapses and suggest that the receptors are not only internalized but also redistributed to select synaptic sites. In the case of Lymnaea, the receptor redistribution did not involve soma-based signaling. Receptor internalization is mainly mediated by clathrindependent endocytosis (Tehrani et al., 1997; Traub and Bonifacino, 2013), and PKC activity has been shown to be important for internalization and/or migration of a variety of receptors to the contact sites (Lan et al., 2001; Mundell et al., 2002; Lin et al., 2006). In addition, BDNF is able to regulate the clathrindependent endocytosis by modifying the dynamin GTPase activity (Smillie et al., 2013). BDNF also exerts actions on the protein trafficking process through direct receptor tyrosine kinase activity and/or indirect coupling to other protein kinases, such as PKC (Vaz et al., 2011). Our studies indeed support the involvement of receptor internalization and $\mathrm{PKC}$ activity in CM-induced redistribution of nAChRs at the postsynaptic LPeD1 axon (Fig. 8). Activation of PKC alone, however, was not sufficient to induce axonal synapse formation. We speculate that trophic factors must act to affect parallel pathways that act synergistically with PKC to trigger receptor clustering and the full complement of molecular mechanisms required for postsynaptic consolidation. These may involve trophic factor-induced activity-dependent intracellular calcium oscillations (Xu et al., 2009). Future experiments are, however, required to test the involvement of trophic factormediated pathway of calcium-PKC in redistribution and clustering of nAChRs to the contact site in axons.

\section{References}

Anderson MJ, Cohen MW (1977) Nerve-induced and spontaneous redistribution of acetylcholine receptors on cultured muscle-cells. J Physiol 268: 757-773. Medline

Barker DL, Wong RG, Kater SB (1982) Separate factors produced by the CNS of the Snail Helisoma stimulate neurite outgrowth and choline metabolism in cultured neurons. J Neurosci Res 8:419-432. CrossRef Medline

Bennett MV, Zukin RS (2004) Electrical coupling and neuronal synchronization in the mammalian brain. Neuron 41:495-511. CrossRef Medline

Berry SA, Khan N, Roth BL (1996) Agonist-induced internalization of the 5HT(2A) receptor in vitro. Biol Psychiatry 39:110.

Bhattacharyya S, Puri S, Miledi R, Panicker MM (2002) Internalization and recycling of 5-HT2A receptors activated by serotonin and protein kinase C-mediated mechanisms. Proc Natl Acad Sci U S A 99:14470-14475. CrossRef Medline

Blum R, Konnerth A (2005) Neurotrophin-mediated rapid signaling in the central nervous system: mechanisms and functions. Physiology 20:70-78. CrossRef Medline

Bodmer R, Verselis V, Levitan IB, Spray DC (1988) Electronic synapses between Aplysia neurons in situ and in culture: aspects of regulation and measurements of permeability. J Neurosci 8:1656-1670. Medline

Bright K, Kellett E, Saunders SE, Brierley M, Burke JF, Benjamin PR (1993) Mutually exclusive expression of alternatively spliced FMRFamide transcripts in identified neuronal systems of the snail Lymnaea. J Neurosci 13:2719-2729. Medline

Broadie KS, Bate M (1993) Development of the embryonic neuromuscular synapse of Drosophila melanogaster. J Neurosci 13:144-166. Medline

Buckett KJ, Peters M, Benjamin PR (1990) Excitation and inhibition of the heart of the snail, Lymnaea, by non-FMRFamidergic motoneurons. J Neurophysiol 63:1436-1447. Medline

Carrow GM, Levitan IB (1989) Selective formation and modulation of elec- trical synapses between cultured Aplysia neurons. J Neurosci 9:36573664. Medline

Chou WH, Wang D, McMahon T, Qi ZH, Song M, Zhang C, Shokat KM, Messing RO (2010) GABA(A) receptor trafficking is regulated by protein kinase $\mathrm{C}$ epsilon and the $\mathrm{N}$-ethylmaleimide-sensitive factor. J Neurosci 30:13955-13965. CrossRef Medline

Chow I, Poo MM (1982) Redistribution of cell-surface receptors induced by cell-cell contact. J Cell Biol 95:510-518. CrossRef Medline

Chow I, Poo MM (1985) Release of acetylcholine from embryonic neurons upon contact with muscle-cell. J Neurosci 5:1076-1082. Medline

Curtin KD, Zhang Z, Wyman RJ (2002) Gap junction proteins expressed during development are required for adult neural function in the Drosophila optic lamina. J Neurosci 22:7088-7096. Medline

Dalva MB, McClelland AC, Kayser MS (2007) Cell adhesion molecules: signalling functions at the synapse. Nat Rev Neurosci 8:206-220. CrossRef Medline

Elmariah SB, Crumling MA, Parsons TD, Balice-Gordon RJ (2004) Postsynaptic $\operatorname{Tr} \kappa \mathrm{B}$-mediated signaling modulates excitatory and inhibitory neurotransmitter receptor clustering at hippocampal synapses. J Neurosci 24:2380-2393. CrossRef Medline

Fan GH, Lapierre LA, Goldenring JR, Sai J, Richmond A (2004) Rab11family interacting protein 2 and myosin $\mathrm{Vb}$ are required for CXCR2 recycling and receptor-mediated chemotaxis. Mol Biol Cell 15:2456-2469. CrossRef Medline

Feng ZP, Klumperman J, Lukowiak K, Syed NI (1997) In vitro synaptogenesis between the somata of identified Lymnaea neurons requires protein synthesis but not extrinsic growth factors or substrate adhesion molecules. J Neurosci 17:7839-7849. Medline

Furshpan EJ, Potter DD (1959) Transmission at the giant motor synapses of the Crayfish. J Physiol 145:289-325. Medline

Gerrow K, Romorini S, Nabi SM, Colicos MA, Sala C, El-Husseini A (2006) A preformed complex of postsynaptic proteins is involved in excitatory synapse development. Neuron 49:547-562. CrossRef Medline

Gibson JR, Beierlein M, Connors BW (1999) Two networks of electrically coupled inhibitory neurons in neocortex. Nature 402:75-79. CrossRef Medline

Giuditta A, Menichini E, Perrone Capano CP, Langella M, Martin R, Castigli E, Kaplan BB (1991) Active polysomes in the axoplasm of the squid giant-axon. J Neurosci Res 28:18-28. CrossRef Medline

Hadley RD, Bodnar DA, Kater SB (1985) Formation of electrical synapses between isolated, cultured helisoma neurons requires mutual neurite elongation. J Neurosci 5:3145-3153. Medline

Hagiwara S, Morita H (1962) Electronic transmission between two nerve cells in leech ganglion. J Neurophysiol 25:721-731. Medline

Hamakawa T, Woodin MA, Bjorgum MC, Painter SD, Takasaki M, Lukowiak K, Nagle GT, Syed NI (1999) Excitatory synaptogenesis between identified Lymnaea neurons requires extrinsic trophic factors and is mediated by receptor tyrosine kinases. J Neurosci 19:9306-9312. Medline

Heeroma JH, Plomp JJ, Roubos EW, Verhage M (2003) Development of the mouse neuromuscular junction in the absence of regulated secretion. Neuroscience 120:733-744. CrossRef Medline

Horch HW, Katz LC (2002) BDNF release from single cells elicits local dendritic growth in nearby neurons. Nat Neurosci 5:1177-1184. CrossRef Medline

Hurst R, Rollema H, Bertrand D (2013) Nicotinic acetylcholine receptor: from basic science to therapeutics. Pharmacol Ther 137:22-54. CrossRef Medline

Jung H, Yoon BC, Holt CE (2012) Axonal mRNA localization and local protein synthesis in nervous system assembly, maintenance and repair. Nat Rev Neurosci 13:308-324. CrossRef Medline

Kirsch J, Betz H (1998) Glycine-receptor activation is required for receptor clustering in spinal neurons. Nature 392:717-720. CrossRef Medline

Kyriakides M, McCrohan CR, Slade CT, Syed NI, Winlow W (1989) The morphology and electrophysiology of the neurons of the paired pedal ganglia of Lymnaea stagnalis. Comp Biochem Physiol A Comp Physiol 93:861-876. CrossRef Medline

Lan JY, Skeberdis VA, Jover T, Grooms SY, Lin Y, Araneda RC, Zheng X, Bennett MV, Zukin RS (2001) Protein kinase C modulates NMDA receptor trafficking and gating. Nat Neurosci 4:382-390. CrossRef Medline

Leal G, Comprido D, Duarte CB (2014) BDNF-induced local protein synthesis and synaptic plasticity. Neuropharmacology 76:639-656. CrossRef Medline 
Leitch B, Cobb JL, Heitler WJ, Pitman RM (1989) Post-embryonic development of rectifying electrical synapses in the Crayfish-ultrastructure. J Neurocytol 18:749-761. CrossRef Medline

Lin Y, Jover-Mengual T, Wong J, Bennett MV, Zukin RS (2006) PSD-95 and PKC converge in regulating NMDA receptor trafficking and gating. Proc Natl Acad Sci U S A 103:19902-19907. CrossRef Medline

Luikart BW, Nef S, Virmani T, Lush ME, Liu Y, Kavalali ET, Parada LF (2005) $\operatorname{Tr} \kappa B$ has a cell-autonomous role in the establishment of hippocampal Schaffer collateral synapses. J Neurosci 25:3774-3786. CrossRef Medline

Luk CC, Naruo H, Prince D, Hassan A, Doran SA, Goldberg JI, Syed NI (2011) A novel form of presynaptic CaMKII-dependent short-term potentiation between Lymnaea neurons. Eur J Neurosci 34:569-577. CrossRef Medline

Meems R, Munno D, van Minnen J, Syed NI (2003) Synapse formation between isolated axons requires presynaptic soma and redistribution of postsynaptic AChRs. J Neurophysiol 89:2611-2619. CrossRef Medline

Mundell SJ, Matharu AL, Pula G, Holman D, Roberts PJ, Kelly E (2002) Metabotropic glutamate receptor 1 internalization induced by muscarinic acetylcholine receptor activation: differential dependency of internalization of splice variants on nonvisual arrestins. Mol Pharmacol 61: 1114-1123. CrossRef Medline

Munno DW, Syed NI (2003) Synaptogenesis in the CNS: an odyssey from wiring together to firing together. J Physiol 552:1-11. CrossRef Medline

Munno DW, Woodin MA, Lukowiak K, Syed NI, Dickinson PS (2000) Different extrinsic trophic factors regulate neurite outgrowth and synapse formation between identified Lymnaea neurons. J Neurobiol 44:20-30. CrossRef Medline

Naik N, Giannini E, Brouchon L, Boulay F (1997) Internalization and recycling of the C5a anaphylatoxin receptor: evidence that the agonistmediated internalization is modulated by phosphorylation of the C-terminal domain. J Cell Sci 110:2381-2390. Medline

Neunuebel JP, Zoran MJ (2005) Electrical synapse formation disrupts calcium-dependent exocytosis, but not vesicle mobilization. Synapse 56: 154-165. CrossRef Medline

Nicholls JG, Liu Y, Payton BW, Kuffler DP (1990) The specificity of synapse formation by identified leech neurons in culture. J Exp Biol 153:141-154.

Park H, Poo MM (2013) Neurotrophin regulation of neural circuit development and function. Nat Rev Neurosci 14:7-23. CrossRef Medline

Pereda AE (2014) Electrical synapses and their functional interactions with chemical synapse. Nat Rev Neurosci 15:250-263. CrossRef Medline

Piper M, Holt C (2004) RNA translation in axons. Annu Rev Cell Dev Biol 20:505-523. CrossRef Medline

Rasse TM, Fouquet W, Schmid A, Kittel RJ, Mertel S, Sigrist CB, Schmidt M, Guzman A, Merino C, Qin G, Quentin C, Madeo FF, Heckmann M, Sigrist SJ (2005) Glutamate receptor dynamics organizing synapse formation in vivo. Nat Neurosci 8:898-905. CrossRef Medline

Ridgway RL, Syed NI, Lukowiak K, Bulloch AG (1991) Nerve growth-factor (Ngf) induces sprouting of specific neurons of the snail, LymnaeaStagnalis. J Neurobiol 22:377-390. CrossRef Medline

Rose CR, Blum R, Kafitz KW, Kovalchuk Y, Konnerth A (2004) From modulator to mediator: rapid effects of BDNF on ion channels. Bioessays 26:1185-1194. CrossRef Medline

Schacher S, Wu F (2002) Synapse formation in the absence of cell bodies requires protein synthesis. J Neurosci 22:1831-1839. Medline

Shapira M, Zhai RG, Dresbach T, Bresler T, Torres VI, Gundelfinger ED, Ziv NE, Garner CC (2003) Unitary assembly of presynaptic active zones from Piccolo-Bassoon transport vesicles. Neuron 38:237-252. CrossRef Medline

Shen K, Cowan CW (2010) Guidance molecules in synapse formation and plasticity. Cold Spring Harbor Perspect Biol 2:a001842. CrossRef Medline

Smillie KJ, Pawson J, Perkins EM, Jackson M, Cousin MA (2013) Control of synaptic vesicle endocytosis by an extracellular signalling molecule. Nat Commun 4:2394. CrossRef Medline

Sotelo C, Dusart I (2009) Intrinsic versus extrinsic determinants during the development of Purkinje cell dendrites. Neuroscience 162:589-600. CrossRef Medline

Stewart AL, Anderson RB, Kobayashi K, Young HM (2008) Effects of NGF, NT-3 and GDNF family members on neurite outgrowth and migration from pelvic ganglia from embryonic and newborn mice. BMC Dev Biol 8:73. CrossRef Medline

Syed NI, Winlow W (1989) Morphology and electrophysiology of neurons innervating the ciliated locomotor epithelium in Lymnaea-stagnalis (L). Comp Biochem Physiol A Physiol 93:633-644. CrossRef

Syed NI, Winlow W (1991) Coordination of locomotor and cardiorespira- tory networks of Lymnaea stagnalis by a pair of identified interneurons. J Exp Biol 158:37-62. Medline

Syed NI, Bulloch AG, Lukowiak K (1990) In vitro reconstruction of the respiratory central pattern generator of the mollusk Lymnaea. Science 250:282-285. CrossRef Medline

Syed N, Richardson P, Bulloch A (1996) Ciliary neurotrophic factor, unlike nerve growth factor, supports neurite outgrowth but not synapse formation by adult Lymnaea neurons. J Neurobiol 29:293-303. CrossRef Medline

Szabo TM, Faber DS, Zoran MJ (2004) Transient electrical coupling delays the onset of chemical neurotransmission at developing synapses. J Neurosci 24:112-120. CrossRef Medline

Tarasova NI, Stauber RH, Choi JK, Hudson EA, Czerwinski G, Miller JL, Pavlakis GN, Michejda CJ, Wank SA (1997) Visualization of G proteincoupled receptor trafficking with the aid of the green fluorescent protein: endocytosis and recycling of cholecystokinin receptor type A. J Biol Chem 272:14817-14824. CrossRef Medline

Tehrani MH, Baumgartner BJ, Barnes EM Jr (1997) Clathrin-coated vesicles from bovine brain contain uncoupled GABA(A) receptors. Brain Res 776:195-203. CrossRef Medline

Terauchi A, Umemori H (2012) Specific sets of intrinsic and extrinsic factors drive excitatory and inhibitory circuit formation. Neuroscientist 18 : 271-286. CrossRef Medline

Todd KL, Kristan WB Jr, French KA (2010) Gap junction expression is required for normal chemical synapse formation. J Neurosci 30:1527715285. CrossRef Medline

Traub LM, Bonifacino JS (2013) Cargo recognition in clathrin-mediated endocytosis. Cold Spring Harbor Perspect Biol 5:a016790. CrossRef Medline

Tyler WJ, Pozzo-Miller LD (2001) BDNF enhances quantal neurotransmitter release and increases the number of docked vesicles at the active zones of hippocampal excitatory synapses. J Neurosci 21:4249-4258. Medline

van Kesteren RE, Gagatek JS, Hagendorf A, Gouwenberg Y, Smit AB, Syed NI (2008) Postsynaptic expression of an epidermal growth factor receptor regulates cholinergic synapse formation between identified molluscan neurons. Eur J Neurosci 27:2043-2056. CrossRef Medline

Vaz SH, Jørgensen TN, Cristóvão-Ferreira S, Duflot S, Ribeiro JA, Gether U, Sebastião AM (2011) Brain-derived neurotrophic factor (BDNF) enhances GABA transport by modulating the trafficking of GABA transporter-1 (GAT-1) from the plasma membrane of rat cortical astrocytes. J Biol Chem 286:40464-40476. CrossRef Medline

Veenstra RD, Beblo DA, Wang HZ, Brink PR (1995) Estimation of connexin channel limiting pore diameters from ionic conductance measurements. Mol Biol Cell 6:1101.

von Zastrow M, Kobilka BK (1992) Ligand-regulated internalization and recycling of human beta-2-adrenergic receptors between the plasmamembrane and endosomes containing transferrin receptors. J Biol Chem 267:3530-3538. Medline

Weidmann S (1952) The electrical constants of Purkinje fibres. J Physiol 118:348-360. Medline

Weisenhorn DM, Roback J, Young AN, Wainer BH (1999) Cellular aspects of trophic actions in the nervous system. Int Rev Cytol 189:177-265. CrossRef Medline

Xie ZP, Poo MM (1986) Initial events in the formation of neuromuscular synapse: rapid induction of acetylcholine-release from embryonic neuron. Proc Natl Acad Sci U S A 83:7069-7073. CrossRef Medline

Xu F, Hennessy DA, Lee TK, Syed NI (2009) Trophic factor-induced intracellular calcium oscillations are required for the expression of postsynaptic acetylcholine receptors during synapse formation between Lymnaea neurons. J Neurosci 29:2167-2176. CrossRef Medline

Ying SW, Futter M, Rosenblum K, Webber MJ, Hunt SP, Bliss TV, Bramham CR (2002) Brain-derived neurotrophic factor induces long-term potentiation in intact adult hippocampus: requirement for ERK activation coupled to CREB and upregulation of Arc synthesis. J Neurosci 22: 1532-1540. Medline

Zhang Xh, Poo MM (2002) Localized synaptic potentiation by BDNF requires local protein synthesis in the developing axon. Neuron 36:675688. CrossRef Medline

Zhou X, Nai Q, Chen M, Dittus JD, Howard MJ, Margiotta JF (2004) Brainderived neurotrophic factor and trkB signaling in parasympathetic neurons: relevance to regulating alpha 7 -containing nicotinic receptors and synaptic function. J Neurosci 24:4340-4350. CrossRef Medline 